https://nv.nltu.edu.ua

https://doi.org/10.15421/40290204

$@ \bowtie$ Correspondence author

Article received 21.02.2019 p.

Article accepted 28.03.2019 p.

H. A. Kryvokhatko

УДК 635.9

С. Б. Ковалевський, Г.А. Кривохатько

Національний університет біоресурсів і природокористування України, м. Київ, Україна

\title{
КОМПЛЕКСНА ОЦІНКА ДЕКОРАТИВНОСТІ РОСЛИН КУЛЬТИВАРІВ THUJА OCCIDENTALIS L.
}

\begin{abstract}
Основна екологічна роль в озелененні міст належить деревним рослинам. 3 декоративними насадженнями тісно пов'язані функціональне зонування міських територій, система транспортних та пішохідних магістралей, прокладення інженерних комунікацій. На сьогодні важливу роль відіграють ті деревні види рослин, які здатні виконувати одночасно декілька функцій: стійкість до умов зростання, не втрачати декоративність впродовж року, відновлювати крону після обрізки. До таких деревних рослин належать рослини Th. occidentalis L. та іiі декоративні культивари, які вирізняються різноманітністю габітусу крони, будовою та забарвленням хвої, невибагливістю до родючості грунту, тіньовитривалістю. Представлено результати комплексної оцінки декоративності рослин культиварів Thuja occidentalis L. в умовах м. Києва за розробленою інтегральною шкалою А. С. Власенко, яка не містить показників зимостійкості, морозостійкості, посухостійкості та жаростійкості рослин. Оцінку декоративних ознак деревних рослин здійснювали за чотирма основними блоками. Перший - це оцінка загальної декоративності рослини, яка включає період декоративності, декоративні ознаки крони (форма, щільність, фактура) та тривалість квітування та облистнення. Другий блок - це оцінка декоративності кори, іï фактури та забарвлення. Третій це оцінка декоративності хвої за формою, розмірами, забарвленням і сезонністю іії змін. Четвертий - це оцінка декоративності генеративних органів, яка грунтується на розмірах, забарвленні, рясності мегастробілів, а також формі, величині, забарвленні та рясності шишок. Дослідними об'єктами були рослини Th. occidentalis та іï культивари, a caмe: Th. oc. 'Wagneriana', Th. oc. 'Wareana Lutescens', Th. oc. 'Ericoides', Th. oc. 'Ellwangeriana', Th. oc. 'Lutescens', Th. oc. 'Columna', Th. oc. 'Globosa', Th. oc. 'Spiralis', Th. oc. 'Smaragd'. Аналіз декоративних властивостей представників виду туя західна свідчить про перспективність та доцільність подальшого розширеного введення досліджуваних видів у зелені насадження м. Києва під час створення садово-паркових об'єктів.
\end{abstract}

Ключові слова: туя західна; декоративні ознаки; забарвлення; сезонність; декоративні культивари.

Вступ. Сучасне видове та формове різноманіття декоративних деревних рослин дає змогу широко використовувати їх для створення різних садово-паркових композицій. Поряд із біологічними і господарськими властивостями рослин, важливим показником використання їх в озелененні є декоративні ознаки. До декоративних ознак деревних рослин належать життєві форми, розміри рослин, форма та розміри крони, форма, будова, колір та тривалість життя листків (хвої), форма, будова, колір і тривалість цвітіння квіток та суцвіть, форма стовбура й текстура кори (Kalinichenko, 2003).

Ці декоративні ознаки мінливі, динамічні, вони змінюються не тільки внаслідок сезонних, але й вікових змін, та істотно залежать від вмілого композиційного застосування в певному ландшафті, а також від генетичних особливостей виду та умов місцезростання. Зазвичай найвищі ознаки декоративності мають ті рослини, котрі зростають в оптимальних екотопічних умовах. Вміле поєднання та врахування цих ознак відіграють важливу роль під час створення садово-паркових композицій. Для об'єктивної оцінки перспективності використання Th. occidentalis L. та іï культиварів в озелененні в умовах Києва важливе значення має оцінка декоративних ознак.
Мета роботи - визначення декоративних властивостей Th. occidentalis L. та іiі культиварів в умовах м. Києва.

Матеріали і методи дослідження. Для декоративної оцінки застосовують різні методичні підходи (Kalinichenko, 2003; Kolesnikov, 1974; Kotelova \& Виноградова, 1974; Sliusar, 2002). Комплексну оцінку декоративних ознак Th. occidentalis L. та iï культиварів здійснювали за чотирма основними блоками (Vlasenko, 2016).

Перший - загальнодекоративна оцінка рослини, яка включає період декоративності, декоративні ознаки крони (форма, щільність, фактура) і тривалість квітування та облистнення.

Другий блок - оцінка декоративності кори, їі фактури та забарвлення.

Третій - оцінка декоративності хвої за формою, розмірами, забарвленням і сезонністю ії змін.

Четвертий блок - оцінка декоративності генеративних органів рослини, яка грунтується на розмірах, забарвленні, рясності мегастробілів, а також формі, величині, забарвленні та рясності шишок.

Загальна декоративна оцінка. Час (період) декоративності - це проміжок часу, впродовж якого рослина не втрачає декоративність (Kolesnikov, 1974).

\section{Інформація про авторів:}

Ковалевський Сергій Борисович, д-р с.-г. наук, професор, кафедра дендрології та лісової селекції. Email: s.kovalevsky@ukr.net Кривохатько Ганна Анатоліївна, майстер виробничого навчання, Ботанічний сад. Email: krivohatko21@ukr.net Цитування за ДстУ: Ковалевський С. Б., Кривохатько Г. А. Комплексна оцінка декоративності рослин культиварів Thuja Occidentalis L. Науковий вісник НЛтУ України. 2019, т. 29, № 2. С. 23-25.

Citation APA: Kovalevskyi, S. B., \& Kryvokhatko, H. A. (2019). Complex assessment of decorative effect of Thuja Occidentalis L. cultivars. Scientific Bulletin of UNFU, 29(2), 23-25. https://doi.org/10.15421/40290204 
Декоративність крони. Важливими декоративними властивостями крони $є$ її форма, щільність та фактура. Крона деревних рослин формується у двох основних напрямках - вертикальному й горизонтальному. Співвідношення між ними визначає форму крони, також ії форму визначає щільність, яка зумовлена системою гілкування. Характер поверхні крони (фактура) залежить від величини та форми хвої та розташування її на гілках (Kaplunenko, 1968).

Ці ознаки відіграють першочергову роль в архітектурних композиціях, i їх варто враховувати під час проектування садово-паркових об'єктів, особливо під час планування солітерних і групових насаджень.

Тривалість пилування - це проміжок часу (у днях) від початку пилування до дня зникнення забарвлення тичинок і припинення видалення пилку (Kaplunenko, 1968).

Тривалість облистнення - це проміжок часу, впродовж якого хвоя залишається на рослині.

Оиінка декоративності кори. Фактура та забарвлення кори - це декоративні властивості стовбура, особливо ці ознаки можуть змінюватись 3 віком рослин та впродовж року, особливо в осінньо-зимовий період. У різних насадженнях ці ознаки сприймаються по-різному. Особливо їх помітно в алейних, рядових та одиничних насадженнях, або якщо крона рослини значно піднята над поверхнею грунту (Vlasenko, 2016; Kalinichenko, 2003). Забарвлення і фактуру кори сприймають переважно із близької відстані. Тому ці декоративні ознаки потрібно брати до уваги під час оформлення перед- ніх планів, створення різних контрастних поєднань (Kaplunenko, 1968).

Оиінка декоративності хвої. Декоративність хвої оцінюють за розмірами, формою, забарвленням і сезонністю його змін.

Оиінка декоративності генеративних органів рослин. Із генеративних органів оцінювали мікро- та мегастробіли рослин Th. occidentalis L. та їі культиварів.

Час цвітіння для абсолютної більшості рослин є періодом найбільшої декоративності. Декоративні властивості квіток залежать від приналежності рослин до систематичних груп. Мікро- та мегастробіли голонасінних дерев не мають такого декоративного значення, як квіти у покритонасінних листяних дерев, але в деяких хвойних вони вносять істотний штрих у загальний вигляд рослин. Для оцінки декоративності рослин Th. occidentalis L. та iii культиварів під час пилування виділено показники розмірів мегастробілів, забарвлення та рясність.

Декоративність шишок. Плоди - дуже ефективне доповнення до декоративності рослин. Декоративність плодів зумовлюється їхніми розмірами, формою, кольором, терміном достигання та обпадання з рослин. У багатьох хвойних порід досить декоративні не тільки зрілі, але й молоді (недозрілі) шишки. У рослин Th. occidentalis L. та iï культиварів у разі рясного утворення шишок естетичний вигляд рослин погіршується.

Для ознак, які погіршують загальний декоративний вигляд рослини (або їм не можливо надати вищу оцінку через відсутність зазначеної ознаки), введено оцінку нуль балів. Докладну шкалу оцінки декоративних ознак Th. occidentalis L. та іiі культиварів наведено в табл. 1.

Табл. 1. Оцінки декоративних ознак Th. occidentalis L. та її культиварів

\begin{tabular}{|c|c|c|c|c|c|c|c|c|c|c|c|c|c|c|c|c|c|c|c|c|c|}
\hline \multirow{3}{*}{ Вид рослин } & \multicolumn{6}{|c|}{$\begin{array}{c}\text { Загальна декоративність рос- } \\
\text { лин }\end{array}$} & \multicolumn{2}{|c|}{$\begin{array}{c}\text { Оцінка } \\
\text { декора- } \\
\text { тивності } \\
\text { кори }\end{array}$} & \multicolumn{4}{|c|}{$\begin{array}{c}\text { Оцінка деко- } \\
\text { ративності } \\
\text { хвої }\end{array}$} & \multicolumn{7}{|c|}{$\begin{array}{l}\text { Оцінка декоративності } \\
\text { генеративних органів }\end{array}$} & \multirow{3}{*}{ 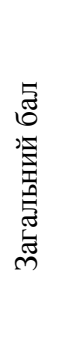 } & \multirow{3}{*}{ 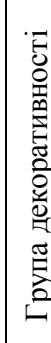 } \\
\hline & \multirow[b]{2}{*}{ 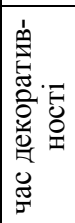 } & \multicolumn{3}{|c|}{ крона } & \multicolumn{2}{|c|}{ тривалість } & \multirow[b]{2}{*}{ 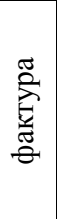 } & \multirow[b]{2}{*}{ 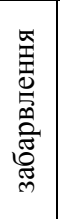 } & \multirow[b]{2}{*}{ 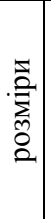 } & \multirow[b]{2}{*}{ 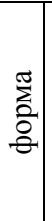 } & \multirow[b]{2}{*}{ 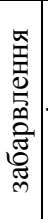 } & \multirow[b]{2}{*}{ 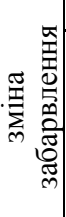 } & \multicolumn{3}{|c|}{ мегастробіли } & \multicolumn{4}{|c|}{ шишки } & & \\
\hline & & 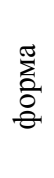 & . & 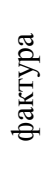 & 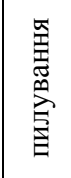 & 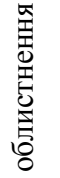 & & & & & & & 胥 & 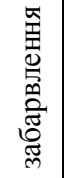 & 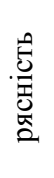 & 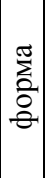 & 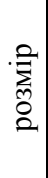 & 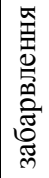 & 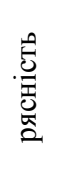 & & \\
\hline Thuja occidentalis L. & 5 & 5 & 3 & 1 & 1 & 5 & 3 & 3 & 1 & 1 & 3 & 3 & 1 & 1 & 1 & 0 & 1 & 3 & 5 & 46 & III \\
\hline Th. oc. 'Wagneriana' & 5 & 3 & 5 & 1 & 0 & 5 & 3 & 3 & 1 & 1 & 3 & 3 & 0 & 1 & 0 & 0 & 1 & 0 & 0 & 35 & IV \\
\hline Th. oc. 'Wareana Lutescens' & 5 & 3 & 5 & 5 & 0 & 5 & 3 & 3 & 1 & 1 & 5 & 3 & 0 & 1 & 0 & 0 & 1 & 0 & 0 & 41 & III \\
\hline Th. oc. 'Ericoides' & 5 & 3 & 5 & 1 & 0 & 5 & 3 & 3 & 1 & 3 & 3 & 5 & 0 & 1 & 0 & 0 & 1 & 0 & 0 & 36 & IV \\
\hline Th. oc. 'Ellwangeriana' & 5 & 3 & 5 & 1 & 1 & 5 & 3 & 3 & 1 & 1 & 3 & 3 & 1 & 1 & 1 & 0 & 1 & 3 & 1 & 42 & III \\
\hline Th. oc. 'Lutescens' & 5 & 3 & 3 & 1 & 1 & 5 & 3 & 3 & 1 & 1 & 5 & 3 & 1 & 1 & 1 & 0 & 1 & 3 & 5 & 46 & III \\
\hline Th. oc. 'Columna' & 5 & 5 & 5 & 5 & 1 & 5 & 3 & 3 & 1 & 1 & 5 & 3 & 1 & 1 & 1 & 0 & 1 & 3 & 5 & 54 & II \\
\hline Th. oc. 'Globosa' & 5 & 3 & 5 & 1 & 1 & 5 & 3 & 3 & 1 & 1 & 3 & 3 & 1 & 1 & 1 & 0 & 1 & 3 & 5 & 46 & III \\
\hline Th. oc. 'Spiralis' & 5 & 3 & 3 & 1 & 1 & 5 & 3 & 3 & 1 & 1 & 3 & 1 & 1 & 1 & 1 & 0 & 1 & 3 & 5 & 42 & III \\
\hline Th. oc. 'Smaragd' & 5 & 5 & 5 & 5 & 1 & 5 & 3 & 3 & 1 & 1 & 5 & 1 & 1 & 1 & 1 & 0 & 1 & 3 & 5 & 52 & II \\
\hline
\end{tabular}

Результати дослідження та їх обговорення. Аналізуючи табл. 1, встановлено, що найвищі бали в першому блоці отримали культивари за загальну декоративність, а саме - за час декоративності та облистнення, оскільки декоративні властивості вони зберігають упродовж усього календарного року. Найменше балів, у першому блоці, отримали за тривалість пилування - 1 бал, оскільки більшості культиварів пилування короткочасне, а деякі культивари взагалі не пилують, тому отримали 0 балів.

Оскільки всі досліджувані культивари за фактурою та забарвленням кори дуже схожі, тому отримали по 3 бали. Низькі бали досліджувані культивари отримали за декоративність генеративних органів, а саме: за розміри та рясність мегастробіл, а за форму шишок взагалі всі культивари отримали 0 балів, оскільки шишки знижують загальну декоративність рослин.

Амплітуда оцінки декоративності рослин змінюється від 13 до 90 балів. Загальну градацію ступенів декоративності рослин наведено в табл. 2.

Табл. 2. Ступені оцінки декоративності дерев та кущів

\begin{tabular}{|c|c|c|c|c|}
\hline Ступінь декора- & $13-40$ & $41-50$ & $51-64$ & $65-90$ \\
\cline { 2 - 5 } тивності, балів & низька & середня & висока & дуже висока \\
\hline $\begin{array}{c}\text { Група декора- } \\
\text { тивності }\end{array}$ & IV & III & II & I \\
\hline
\end{tabular}

Незважаючи на низькі бали, більшість культиварів отримали досить високий загальний результат. Два культивари, Th. oc. 'Wagneriana', Th. oc. 'Ericoides', ма- 
ють низький загальний бал - відповідно 35 та 36 балів, та належать до четвертої групи декоративності; до третьої групи - найбільша кількість досліджуваних рослин: Thuja occidentalis L., Th. oc. 'Wareana Lutescens', Th. $o c$. 'Ellwangeriana', Th. oc. 'Lutescens', Th. oc. 'Globosa', Th. oc. 'Spiralis'; до другої групи, які мають високу декоративність, належать Th. oc. 'Smaragd' та Th. oc. 'Columna'. Ці рослини мають найвищий бал - відповідно 54 та 52 бали. До першої групи не потрапив жодний з досліджуваних культиварів.

Висновки. Отримані результати аналізу декоративних властивостей культиварів туї західної свідчать про перспективність та доцільність подальшого розширеного введення досліджуваних рослин у зелені насадження Києва під час створення садово-паркових об'єктів. Однак у разі проектування насаджень 3 використанням культиварів Thuja occidentalis L. перевагу варто надавати ділянкам із добрим освітленням, оскільки в тіні та під наметом дерев крона хвойних рослин втрачає декоративні властивості.

\section{Перелік використаних джерел}

Kalinichenko, O. A. (2003). Decorative dendrology. Kyiv: Vyshcha Shkola, 199 p. [In Ukrainian].

Kaplunenko, M. F. (1968). TThuja and east biota in gardening in Ukraine. Kyiv: Naukova dumka, 87 p. [In Ukrainian].

Kolesnikov, A. I. (1974). Decorative dendrology. Moscow: Lesn. prom., 703 p. [In Russian].

Kotelova, N. V., \& Виноградова, О. Н. (1974). Assessment of decorative effect of trees and bushes depending on season. Fiziolohia $i$ selektsia rastenii i ozelenenie horodov, 51, 37-44. [In Russian].

Sliusar, S. I. (2002). Determination of the seasonal decorative effect of species of Taxodiaceae family, which are introduced into Rightbank Forest Steppe of Ukraine. Introduktsiia roslyn, 2, 96-100. [In Ukrainian].

Vlasenko, A. S. (2016). Assessment of decorative effect of ex situ dendrosozoexot of Ukrainian Steppe. (Ser. Botanika). Naukovyi visnyk Skhidnoievropeiskoho natsionalnoho universytetu imeni Lesi Ukrainky, 7, 27-35. [In Ukrainian].

S. B. Kovalevskyi, H. A. Kryvokhatko National University of Life and Environmental Sciences of Ukraine, Kyiv, Ukraine

\section{COMPLEX ASSESSMENT OF DECORATIVE EFFECT OF THUJA OCCIDENTALIS L. CULTIVARS}

The main ecological role in gardening of cities belongs to tree plants. The functional zoning of urban areas, the system of transport and pedestrian highways, and the laying of engineering communications are closely linked with decorative plantations. At present, the important role is played by those tree species of plants that can perform several functions simultaneously: resistance to growing conditions, not to lose decorative character throughout the year, to restore the crown after trimming. Such tree plants include plants Th. occidentalis L. and its decorative cultivars, which are distinguished by the diversity of crown habitatus, the structure and color of the needles, the unpretentiousness of soil fertility, and shadedness. Results of complex assessment of decorative effect of Thuja occidentalis L. cultivars in the conditions of Kiev city, under the developed integrated scale of A. S. Vlasenko, which does not include indicators of winter hardiness, frost resistance, drought resistance and heat resistance of plants, are presented. The assessment was made on four main units. The first one is the assessment of the overall decorative nature of the plant, which includes the period of decorative, decorative features of the crown (form, density, texture) and the duration of flowering and flaking. The second block is an assessment of the decorative nature of the crust, its texture and color. The third is the assessment of the decorative properties of the needles in shape, size, color and seasonality of its changes. The fourth is the assessment of decorative organs of generative organs, which is based on the size, color, abundance of megastrobes, as well as the shape, size, color and abundance of cones. Plants of Th. occidentalis and its cultivars were the objects of the research, as follows: Th. oc. 'Wagneriana', Th. oc. 'Wareana Lutescens', Th. oc. 'Ericoides', Th. oc. 'Ellwangeriana', Th. oc. 'Lutescens', Th. oc. 'Columna', Th. oc. 'Globosa', Th. oc. 'Spiralis', Th. oc. 'Smaragd'. The analysis of decorative qualities of representatives of Thuja occidentalis species, shows good prospects and usefulness of a further expanded introduction of the studied species to green plantings of Kiev city, when landscape gardening objects are made.

Keywords: Thuja occidentalis; decorative signs; coloring; seasonality; decorative cultivars. 